\title{
What can we learn from confusing Olivella columellaris and $O$. semistriata (Olivellidae, Gastropoda), two key species in panamic sandy beach ecosystems?
}

\author{
Alison I. Troost ${ }^{1}$, Samantha D. Rupert ${ }^{1}$, Ariel Z. Cyrus $^{1}$, Frank V. Paladino ${ }^{1,2}$, \\ Benjamin F. Dattilo ${ }^{3}$ \& Winfried S. Peters ${ }^{1,2,4}$ \\ ${ }^{1}$ Department of Biology, Indiana/Purdue University Fort Wayne, 2101 East Coliseum Boulevard, \\ Fort Wayne, IN 46805-1499, USA \\ ${ }^{2}$ Goldring Marine Biology Station, Playa Grande, Santa Cruz, Guanacaste, Costa Rica \\ ${ }^{3}$ Department of Geosciences, Indiana/Purdue University Fort Wayne, 2101 East Coliseum Boulevard, \\ Fort Wayne, IN 46805-1499, USA \\ ${ }^{4}$ Corresponding author: Winfried S. Peters, e-mail: peters@ipfw.edu
}

TROOST, A.I., RUPERT, S.D., CYRUS, A.Z., PALADINO, F.V., DATTILO, B.F. \& PETERS, W.S. What can we learn from confusing Olivella columellaris and $O$. semistriata (Olivellidae, Gastropoda), two key species in panamic sandy beach ecosystems? Biota Neotrop. 12(2): http://www.biotaneotropica.org.br/v12n2/ en/abstract?article+bn02112022012

\begin{abstract}
Olivella columellaris (Sowerby 1825) and O. semistriata (Gray 1839) are suspension-feeding, swash-surfing snails on tropical sandy beaches of the east Pacific. While they often are the numerically dominant macrofaunal element in their habitats, their biology is poorly understood; the two species actually have been confused in all of the few publications that address their ecology. Frequent misidentifications in publications and collections contributed also to an overestimation of the geographic overlap of the two species. To provide a sound taxonomic basis for further functional, ecological, and evolutionary investigations, we evaluated the validity of diagnostic traits in wild populations and museum collections, and defined workable identification criteria. Morphometric analysis demonstrated that shell growth is allometric in $O$. columellaris but isometric in $O$. semistriata, suggesting that the species follow distinct developmental programs. The taxonomic confusion is aggravated by the existence of populations of dwarfish $O$. semistriata, which originally had been described as a separate species, O. attenuata (Reeve 1851). At our Costa Rican study sites, the occurrence of such dwarfish populations correlates with low wave energies but not with predation pressure and anthropogenic disturbances, indicating significant ecological plasticity in the development of $O$. semistriata.

Keywords: Olivella, Pachyoliva, panamic faunal province, sandy beach intertidal, shell growth (allometry), suspension feeder.
\end{abstract}

TROOST, A.I., RUPERT, S.D., CYRUS, A.Z., PALADINO, F.V., DATTILO, B.F. \& PETERS, W.S. ¿Qué podemos aprender de la confusión de la Olivella columellaris y la $O$. semistriata (Olivellidae, Gastropoda), dos especies con un papel clave en los ecosistemas de las playas arenosas panamicas? Biota Neotrop. 12(2): http://www.biotaneotropica.org.br/v12n2/pt/abstract?article+bn02112022012

Resumen: La Olivella columellaris (Sowerby 1825) y la O. semistriata (Gray 1839) son caracoles filtradores que navegan en la zona de vaivén de las playas arenosas tropicales del Pacífico oriental. Si bien son frecuentemente el elemento macrofáunico dominante en su habitat, su biología está insuficientemente entendida; de hecho, las dos especies han sido confundidas en las pocas publicaciones que han tratado de su ecología. La identificación equivocada tanto en las publicaciones como en las colecciones ha contribuido también a sobrestimar el solapamiento geográfico de las dos especies. Para proporcionar una base taxonómica segura para futuras investigaciones funcionales, evolutivas y ecológicas, evaluamos la validez de los rasgos diagnósticos en poblaciones silvestres y en colecciones museísticas, y definimos criterios de identificación para ser usados. El análisis morfométrico mostró que el crecimiento de la concha es alométrico en la $O$. columellaris pero isométrico en la $O$. semistriata, lo que sugiere que las dos especies siguen programas de desarrollo diferentes. La confusión taxonómica se ha visto agravada por la existencia de poblaciones de $O$. semistriata enanas, que fueron originalmente descritas como una especie separada: $O$. attenuata (Reeve 1850). En nuestro sitio de estudio en Costa Rica, la ocurrencia de tales poblaciones enanas se correlaciona con olas de baja energía, y no con la presión de depredación ni con disturbios antropogénicos, lo que indica una plasticidad ecológica considerable en el desarrollo de la O. semistriata. Palabras clave: Olivella, Pachyoliva, provincia fáunica panamica, zona intermareal de playa arenosa, crecimiento de concha (alometría), animales filtradores. 


\section{Introduction}

The macrofaunal communities on many dissipative sandy beaches of the panamic faunal province (American west coast from Baja California to north Peru) are numerically dominated by two closely related species of intertidal snails, Olivella columellaris (Sowerby 1825 ) and $O$. semistriata (Gray 1839). These very similar species must be assumed to be ecological key players due to their immense densities on those beaches (Olsson 1923/1924, 1956, Aerts et al. 2004), but our knowledge of their biology is fragmentary. According to Olsson (1956), the two species form the subgenus Pachyoliva in the genus Olivella (Olivellidae, Caenogastropoda, Gastropoda; while Olsson had included Olivella in the Olividae, we here follow the more recent suggestion by Bouchet \& Rocroi (2005) to separate Olivellidae and Olividae). Olivella semistriata appears to be the more northerly species frequently found on Central American beaches, whereas $O$. columellaris seems to be common in South America (Olsson 1956). From previous casual field observations of $O$. semistriata at Playa Grande, Costa Rica, and of $O$. columellaris at Colan, Peru, we conclude that both species are swash surfers that reposition themselves in the sandy intertidal using their expanded foot as an underwater sail for rapid locomotion. Moreover, both use a pair of mucus nets suspended from unique lateral appendages of the anterior foot to filter suspended particles from the backwash in the upper beach zone. These observations are not novel, as similar reports regarding ' $O$. columellaris' can be found in the older literature (Seilacher 1959). However, in all of the few papers published on the functional biology and ecology of Pachyoliva in peer-reviewed journals, the two species have been confused, as we will demonstrate below. Such confusion obviously hampers our understanding of the biology of the two species, and prevents the detection and analysis of any behavioral, physiological, and developmental differences that may throw light on their ecological role on panamic beaches and on the evolution of their clade. We analyzed the classical literature and conducted morphometric studies of populations in the field and of museum collections, in order to identify and resolve taxonomic and morphological issues that have caused the confusion.

\section{Material and Methods}

\section{Analysis of diagnostic traits and morphometric studies}

Live Olivella columellaris (Sowerby 1825), O. semistriata (Gray 1839 ), and $O$. biplicata (Sowerby 1825) were studied in their natural habitats, mainly at Colan, Piura, Peru ( $04^{\circ} 59^{\prime} \mathrm{S}$ and $\left.81^{\circ} 05^{\prime} \mathrm{W}\right)$, at Playa Grande, Guanacaste, Costa Rica ( $10^{\circ} 20^{\prime} \mathrm{N}$ and $\left.85^{\circ} 51^{\prime} \mathrm{W}\right)$, and at Bodega Bay, California, USA ( $38^{\circ} 19^{\prime} \mathrm{N}$ and $123^{\circ} 02^{\prime} \mathrm{W}$ ), respectively. Shells of the former two species in the collections of the Senckenberg Museum of Natural History in Frankfurt, Germany (http://www.senckenberg.de), and of the Natural History Museum in London, UK (http://www.nhm.ac.uk), were also examined. Additional field observations from various locations along the Pacific coasts of El Salvador, Costa Rica, and Peru are included in this report. For morphometric analyses, we measured shell length, shell width, spire height, and spire base width (Figure 1) of animals in the field and in the museum collections to the nearest $0.05 \mathrm{~mm}$ with digital calipers.

\section{Microscopy of shells}

Cross sections of shells were prepared by embedding cleaned shells in plastic cylinders with epoxy resin, slicing the cylinders at $1 \mathrm{~mm}$ intervals, adhering the slices to glass slides with epoxy, and grinding them to approximately $30 \mu \mathrm{m}$ thickness. The thin sections were examined under glass cover-slips with glycerine using a Leica
Z16 APO Macroscope with a DFC490 digital camera and polarization equipment (Leica, Wetzlar, Germany).

\section{Comparative ecological studies of Olivella semistriata populations}

Eight test beaches in northwest Costa Rica (Figure 2) known from previous visits to home dense populations of $O$. semistriata were selected for investigations into the dependence of maximum body size on local ecological conditions. In Table 1, the test beaches are listed according to their exposure to wave energy. The highest degree of exposure was defined as that found in dissipative sandy beaches forming part of long linear or even convex coastlines, whereas the lowest degree was assigned to coves in the interior of complex coast geometries providing shelter from open ocean conditions. It is worth noting that the degree of wave exposure thus defined generally correlated with the type of human activity: high-exposure beaches are frequented mostly by surfers, whereas low-exposure sites typically are family-friendly bathing beaches. With respect to the extent of human utilization, the eight test beaches ranged from pristine without significant tourist infrastructure to strongly impacted by tourism and other activities due to a 'downtown location'.

Local maximum body size and predation pressure were evaluated on the test beaches between November 20 and 27, 2010 (end of the rainy season), during daylight hours following a standardized procedure. Exactly two hours before low tide, we began to screen a beach for the predatory snail Agaronia propatula (Conrad 1849; Olividae, Gastropoda) which feeds mostly on O. semistriata (Cyrus et al. 2012), by slowly walking in a zigzag pattern between the uppermost waterline occasionally reached by the highest waves

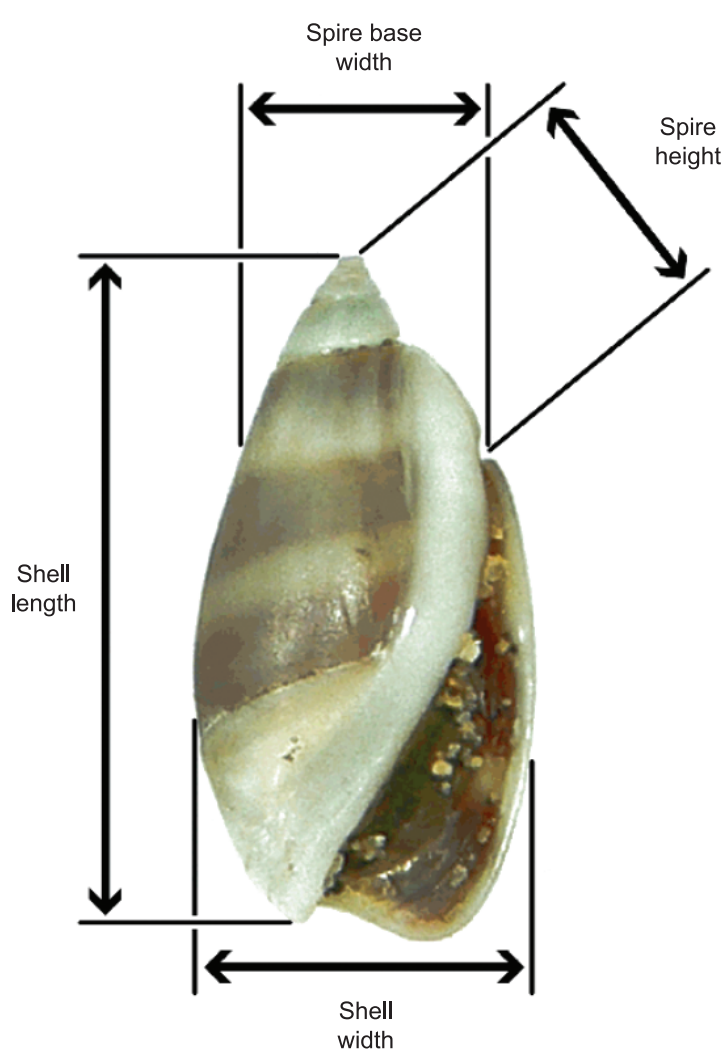

Figure 1. Definition of the measures taken on shells of Olivella columellaris and $O$. semistriata. 


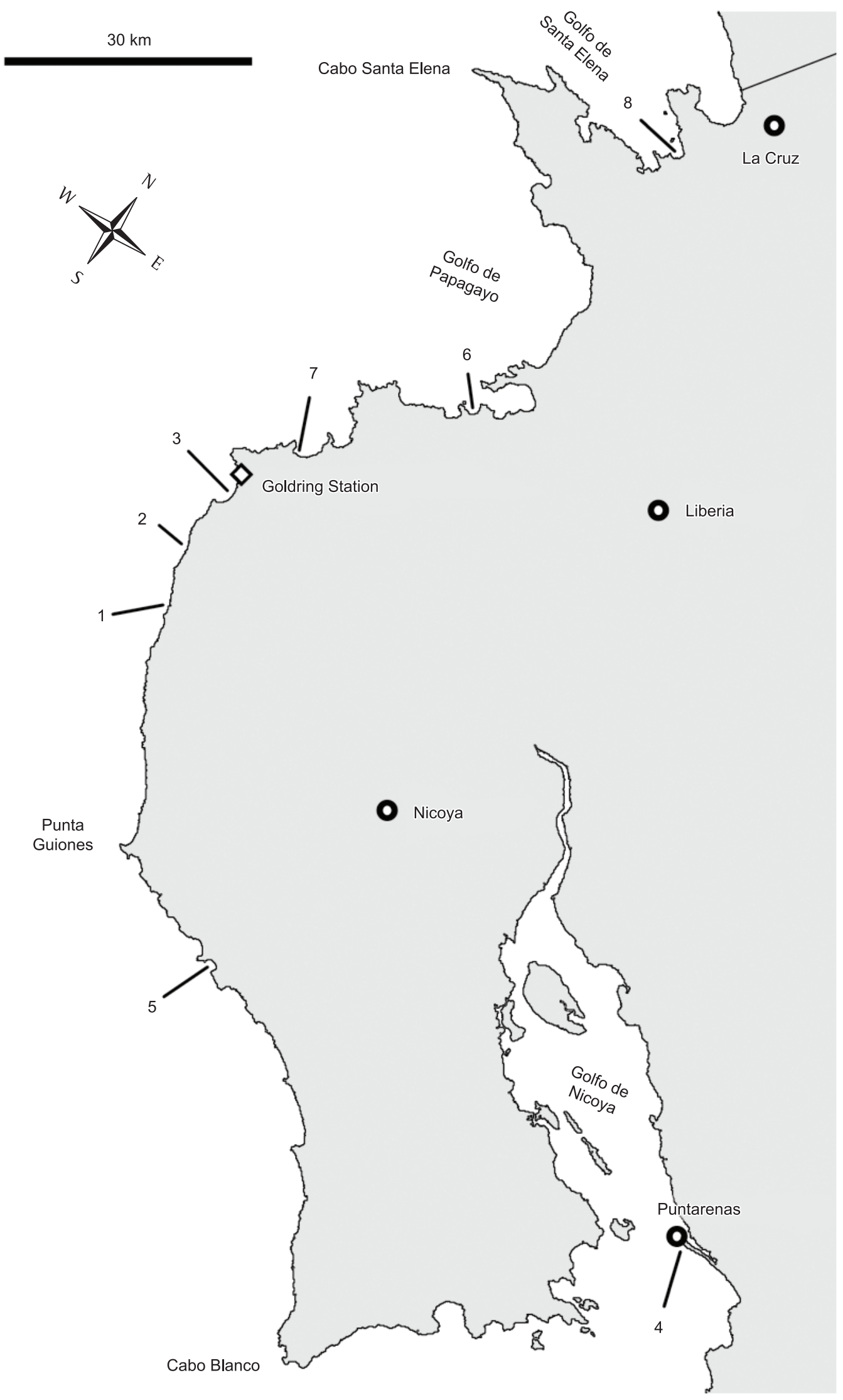

Figure 2. Locations of the eight test beaches in Northwest Costa Rica. 1) Playa Junquillal; 2) Playa Avellana; 3) Playa Grande; 4) city beach of the town of Puntarenas; 5) Playa Carrillo; 6) Playa Hermosa; 7) Playa Conchal; 8) Bahia Junquillal. For further details, see Table 1. 
Troost, A.I. et al.

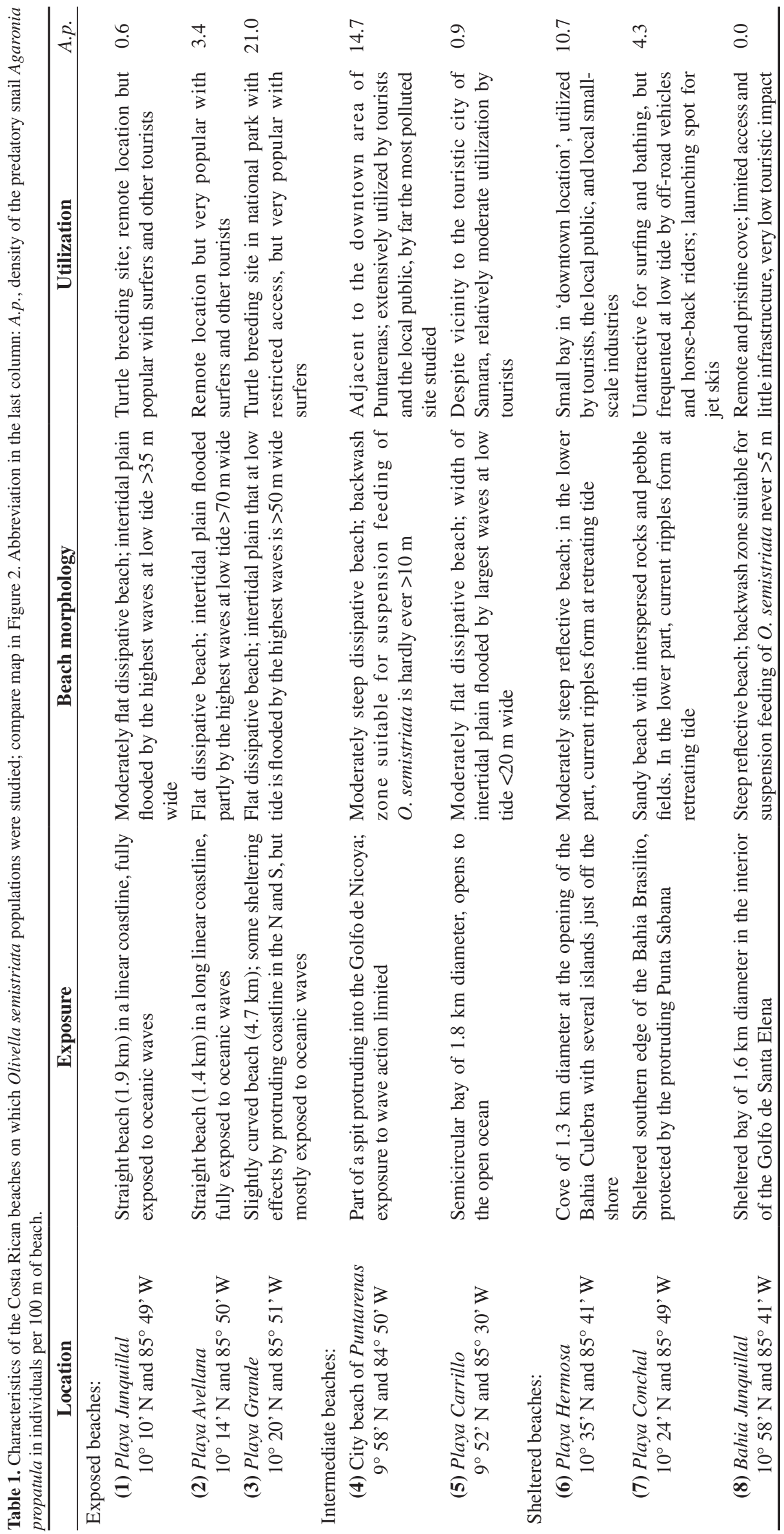


and a line where the water was about ankle-deep (10 to $20 \mathrm{~cm}$ ) during the phases of wave retreat. After two hours (that is, at low tide), the counting of Agaronia was stopped. The estimated density of Agaronia was expressed as the number of individuals per $100 \mathrm{~m}$ of beach. Obviously, this number provided a relatively crude minimum estimate of the true density of Agaronia in the intertidal zone since only actively hunting individuals that were visible on the surface were counted. In the following two hours, the same stretch of beach was screened for particularly large specimens of $O$. semistriata. Their shell lengths were measured to the nearest $0.05 \mathrm{~mm}$ with digital calipers; the animals were put back to their original location immediately. Up to 80 and not less than 52 individual measurements were taken on each beach; these particularly large animals represented a tiny minority of the total population present at each site. The 25 largest animals found on a given beach were selected from each dataset and their size spectrum served as an estimate of the maximum size which $O$. semistriata reached at that location. To transform shell length measurements into biomass, shell length as well as the weight of the live animals (measured to the nearest $0.01 \mathrm{~g}$ ) were determined for a representative sample of 266 individuals from Playa Grande that was selected to cover all size classes. The relation between shell length and body mass was expressed as the geometric mean functional relationship (GMFR), a type II correlation model (Laws \& Archie 1981).

\section{Results and Discussion}

\section{The subgenus Pachyoliva}

In the most recent revision of extant and extinct members of the genus Olivella, Olsson (1956) established a number of subgenera, mainly based on shell characteristics. However, the most obvious morphological characters that identify the subgenus Pachyoliva (comprising $O$. columellaris and $O$. semistriata) are found in the anterior soft body. Olivella generally lacks eyes and cephalic tentacles, and the most anterior portion of the foot (propodium) is set off against the main part (metapodium) by a shallow groove. The tips of the crescent-shaped propodium protrude slightly from the lateral edges of the foot in most species (Figure 3a shows $O$. biplicata as a typical example). In contrast, the lateral tips of the propodium are thickened and elongated in $O$. semistriata and $O$. columellaris (Figures 3b, c). In live animals, these enlarged propodial tips are quite conspicuous and occasionally have been confused with cephalic tentacles, for instance by Gray (1839) in the original description of O. semistriata. This author included the species in Oliva rather than in Agaronia, precisely because Oliva possesses cephalic tentacles whereas Agaronia does not (Gray 1839 p. 129). In fact, however, the elongated propodial tips are unknown from other Olivellidae and Olividae, and thus represent an autapomorphy of Pachyoliva. A smaller, less conspicuous appendage protrudes from each side of the
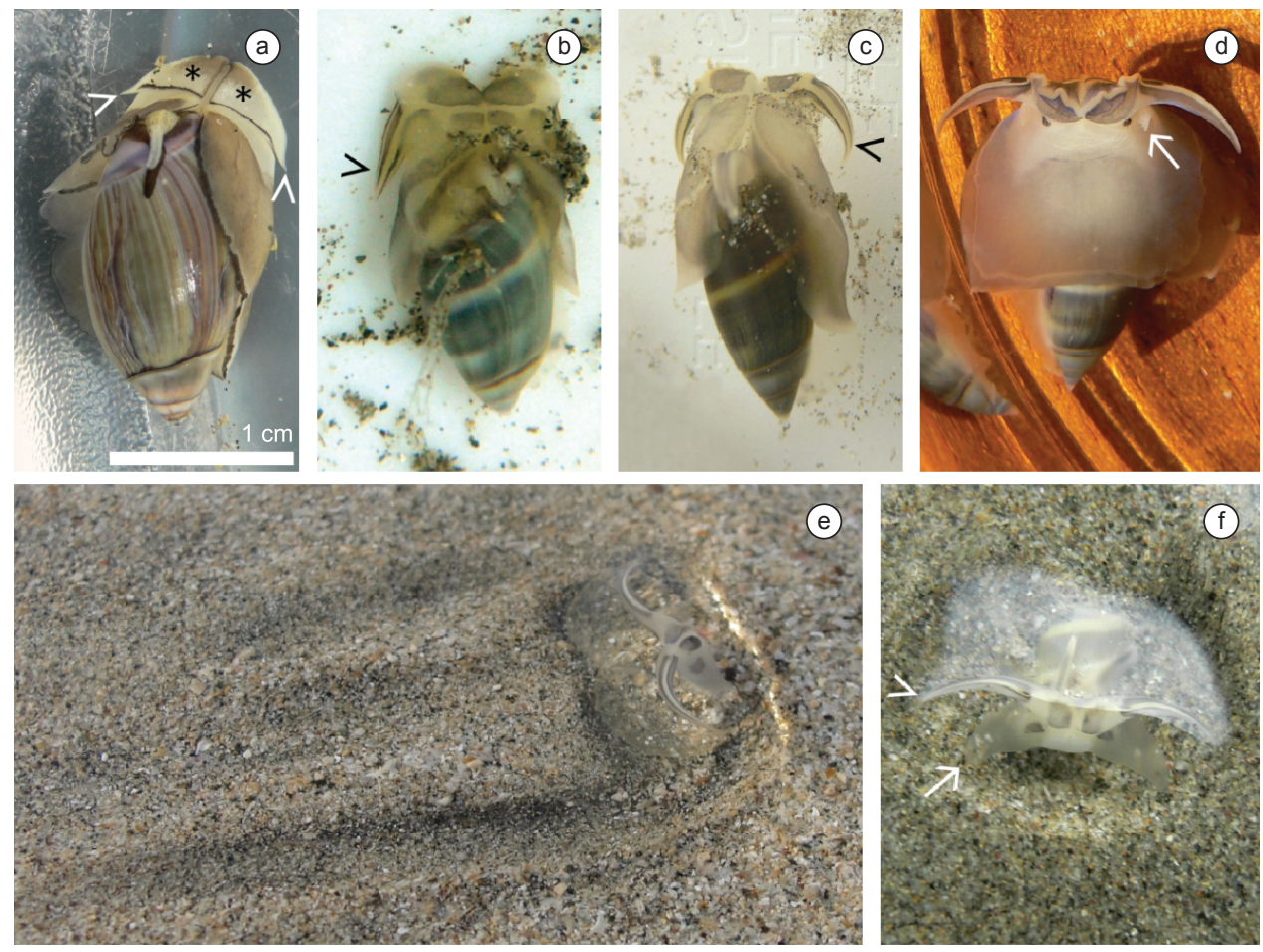

Figure 3. Morphology of Olivella species. a) O. biplicata (from Bodega Bay, California, USA) as an example of the typical morphology of the genus. Cephalic tentacles carrying eyes are absent; the left and right halves of the propodium (asterisks) are visually separated from the metapodium by transverse dark lines, and the lateral tips of the propodium (arrowheads) extend slightly beyond the lateral edges of the foot. These lateral propodial tips are greatly enlarged in the two members of the subgenus Pachyoliva: b) O. columellaris from Colan, Peru, and c) O. semistriata from Playa Grande, Costa Rica. d) A smaller lateral appendage is present on each side of the anterior metapodium, highlighted here by the arrow in a ventral view of an $O$. semistriata that has assumed the surf posture. e) Food acquisition by $O$. semistriata in the backwash; direction of water flow from right to left. The snail has burrowed into the sand; only the propodium and most anterior metapodium extend above the surface. The lateral propodial appendages arch outwards and support translucent mucus nets that balloon in the flow; at this late stage in the filtering cycle, the nets have accumulated suspended detritus and are clearly visible. A characteristic trident flow mark has formed downstream of the animal. f) Head-view of a filtering $O$. columellaris; direction of water flow from bottom to top. The mucus nets are suspended between the propodial (arrowhead) and the greatly expanded metapodial (arrow) appendages, but are not yet visible in this early stage of the filtering cycle. Scale bar in a) applies to all photographs. 
anterior metapodium (Figure 3d, f). These metapodial appendages, which have not been described previously, appear to be absent in species with typical foot morphology such as $O$. biplicata. Pachyoliva snails use their foot appendages to deploy mucus nets for suspension feeding in the backwash of sandy beaches: one semispherical net is suspended on each side between the large propodial and small metapodial appendage (Figure 3e, f). As noted by Seilacher (1959), these nets are hard to see at the beginning of a filtering cycle, before they have become loaded with plankton and detritus (Figure 3f).

According to modern identification keys (Olsson 1956, Burch \& Burch 1963, Keen 1971), the two species can be distinguished using two structural characters of the shells (shell coloration, a feature focused on by many classical authors, is variable and of little diagnostic value). First, while shells of both species exhibit callus on the inner lip (parietal callus) that extends beyond the posterior end of the aperture (spire callus), callus development supposedly is stronger in $O$. columellaris. Second, only O. semistriata is thought to possess fine, longitudinal striae that cover the upper half of the body whorl, as the species name indicates. In addition, shells of $O$. columellaris frequently were described as stockier than those of $O$. semistriata; especially the spire of the latter was claimed to be higher and more sharply pointed. Finally, it is worth noting that in the modern keys, similar sizes (14-15 mm length) are given for mature shells of both species.

\section{Critical evaluation of diagnostic shell characters and their application}

To evaluate the usefulness of the above diagnostic criteria in field studies, we examined populations of $O$. columellaris in Peru and of O. semistriata in Costa Rica, as well as the extensive collection of the Senckenberg Museum which houses, among others, the shells collected by the authors of the first ecological studies of Pachyoliva (Schuster 1952, Schuster-Dieterichs 1956, Seilacher 1959).

Callus - In 'typical' specimens of $O$. columellaris resembling those shown in identification guides (Figure 4a), the parietal and spire callus is more strongly developed than in 'typical' O. semistriata (Figure 4b). Strong spire callus formation in $O$. columellaris causes a characteristic kink in the outline of the shell at the suture above the body whorl (highlighted in Figure 4a), which, according to the original species description by Sowerby (1825, Appendix p. 34), "[...] gives to this shell a very extraordinary appearance, and forms the characteristic feature of the species." However, in every O. columellaris population that we have seen in the field, specimens without strongly developed spire callus (Figure 4c) actually were more abundant than 'typical' shells. Analysis of a representative sample $(n=315)$ of $O$. columellaris shells from our study site at Colan, Peru, indicated that the 'typical' morphology does not develop before the animals grow from 10 to $13 \mathrm{~mm}$ shell length (Figure $4 \mathrm{~d}$ ).
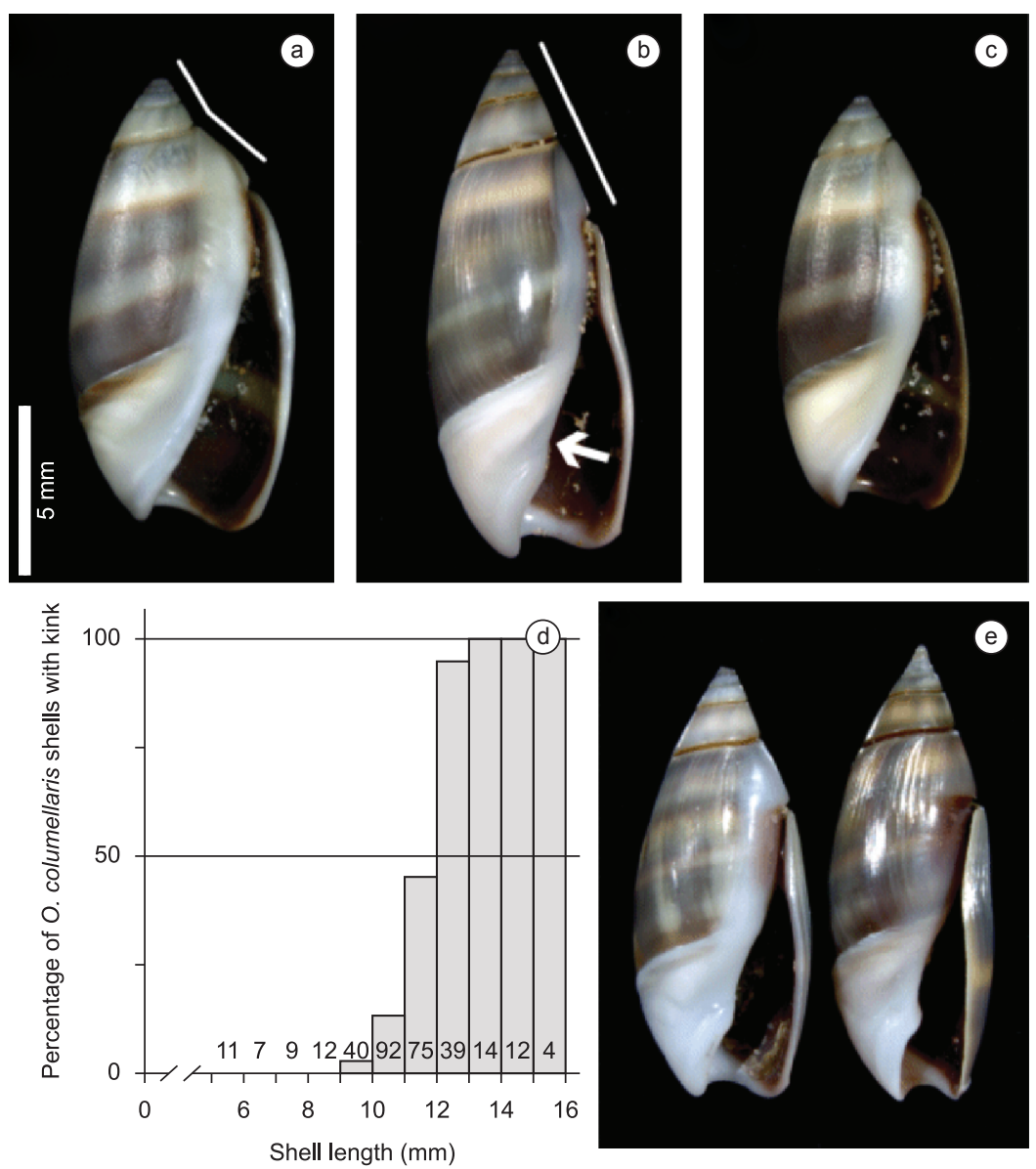

Figure 4. Callus formation in Pachyoliva shells. a) 'Typical' O. columellaris shell from Colan, Peru, showing a kink in the outline of the shell above the aperture (highlighted by white line). b) 'Typical' O. semistriata shell from Playa Grande, Costa Rica. The outline of the shell above the aperture is straight (highlighted by white line). Note the notch in the anterior inner lip (arrow). c) 'Atypical' specimen of $O$. columellaris from the same population as the shell in a); no kink in the outline of the shell is visible. d) Proportion of $O$. columellaris shells with kinked outline in size classes defined by shell length ( 1 mm class width), determined in the population of Colan, Peru. Numbers at the bases of the bars indicate the number of animals examined in that size class. e) Two O. semistriata from Playa de Cuco, El Salvador, demonstrating the variability of callus formation in this species. Scale bar in a) applies to all photographs. 
The situation is further complicated by the significant variability of callus formation in $O$. semistriata. If the extent of spire callus were the only diagnostic criterion available, the two shells shown in Figure 4e probably would be classified as $O$. columellaris (left) and $O$. semistriata (right). In fact, the two shells come from the same $O$. semistriata population in east El Salvador, and both show the striae that are characteristic of this species (see below). We have found individuals with similarly strongly developed callus as the one on the left in numerous $O$. semistriata populations in Central America, but this always was a minority phenotype.

Striae - In the words of Keen (1971 p. 631), a "[...] faint series of vertical striae at the upper margin of the body whorl is distinctive." in $O$. semistriata. These structures were explicitly highlighted in the species description (Gray 1839 p. 130), and the name semistriata refers to them. The striae are unmistakable in clean and dry shells from which the light reflects (Figure 5a), but may be overlooked in the field especially under poor light. They are spaced at 230-300 $\mu \mathrm{m}$, which corresponds to the geometry of the internal crenulation and terminations of prominent laminae within the outermost shell layer (Figure $5 \mathrm{~b}, \mathrm{c}$ ). While the striae reflect a distinct process of routine shell accretion in $O$. semistriata, they do not resemble and must not be confused with the major growth lines that may form in response to disruptions of growth, either from trauma or during senescence, in both Pachyoliva species. Small O. semistriata shells lack striae; at our study site Playa Grande in Costa Rica, striae gradually occurred in the size classes from 7 to $12 \mathrm{~mm}$ shell length (Figure 5d; size of the representative sample examined, $n=267$ ) and were never lacking in larger animals. In contrast, we failed to find even a single semi-striated shell among the northern Peruvian populations that we had identified as $O$. columellaris due to the presence of individuals showing the 'typical' callus (this identification was in agreement with classical studies undertaken at the same localities; Olsson 1923/1924). Intriguingly, Olsson (1956) did not even mention the characteristic striae in his description of $O$. semistriata. The O. semistriata shell
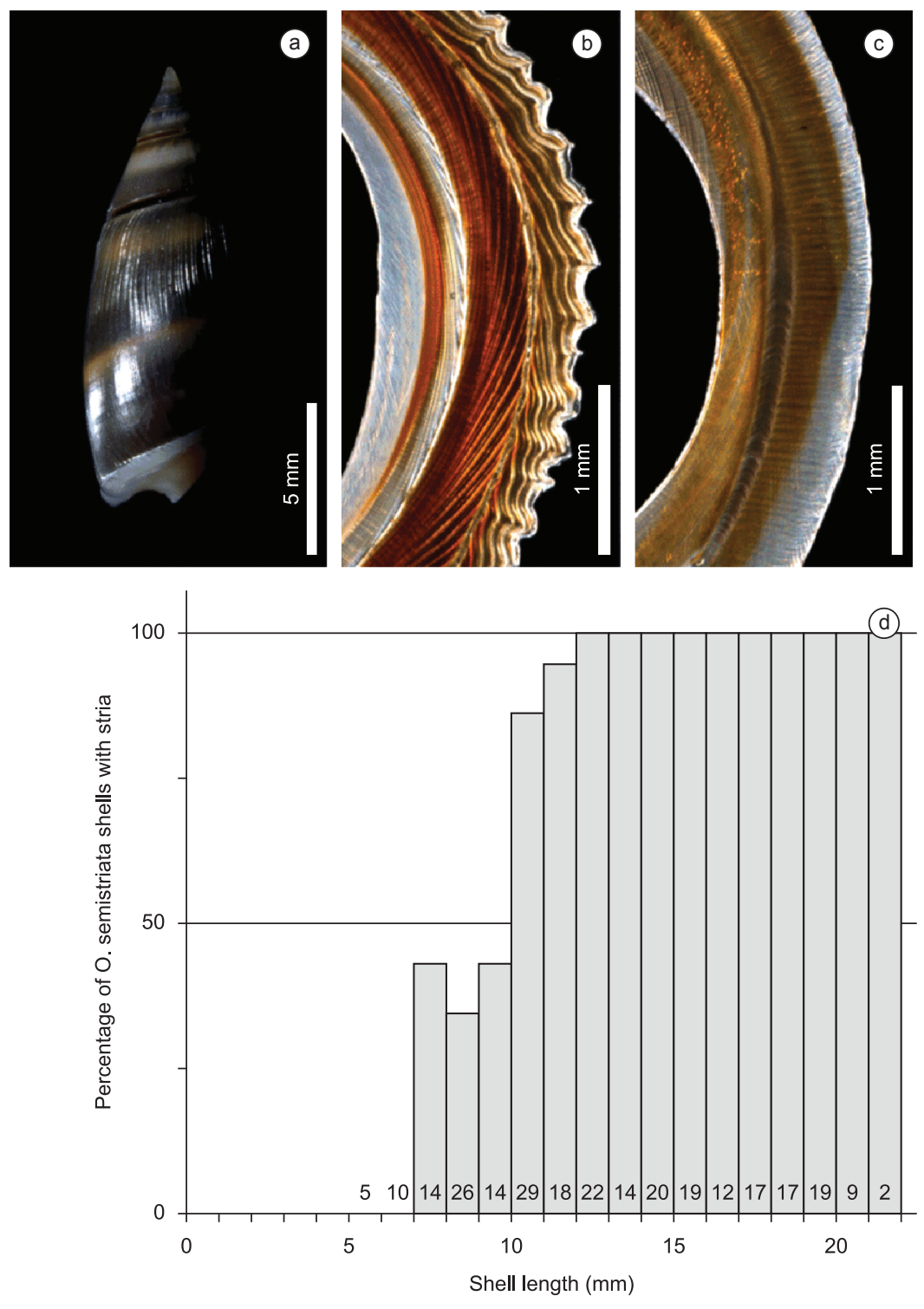

Figure 5. Striae on the shell of Olivella semistriata. a) Light reflections from an $O$. semistriata shell reveal the structural difference between the striated upper (posterior) part and the smooth lower (anterior) part of the body whorl. b) Cross-section of an O. semistriata shell, taken from the uppermost quarter of the body whorl. The striae on the surface correspond to terminations of individual laminae in the outermost shell layer. c) No striae are present in the shell of $O$. columellaris. d) Proportion of $O$. semistriata shells with visible striae in size classes defined by shell length ( $1 \mathrm{~mm}$ class width), determined in the population of Playa Grande, Costa Rica. Numbers of individuals examined in each size class are given at the bases of the bars. 
shown on this author's Plate 8 was $14.2 \mathrm{~mm}$ long, according to the plate legend (Olsson 1956 p. 219), but the quality of the image is not sufficient to determine unambiguously whether striae were present or not. In any case, it is puzzling that Olsson ignored this defining trait, and we assume that he mainly studied immature shells too small to show this feature.

Large shells of $O$. semistriata but not of $O$. columellaris often show a notch in the anterior inner lip (Figure $4 \mathrm{~b}$ ). This character is not unambiguously expressed in small $O$. semistriata shells (data not shown), and therefore merely confirms conclusions that can be drawn from the presence or absence of striae on the posterior body whorl. Moreover, the notch, if present, frequently is covered by the foot tissue in live animals retracted into the shell, and therefore is not a suitable character for the routine identification of live specimens in ecological field studies.

From these findings we concluded that, despite all phenotypic variability, it is possible to establish the taxonomic identity of a Pachyoliva population based on the presence of striae in the posterior body whorls (Figure 5) and of kinks in the shell outline caused by spire callus (Figure 4), as long as a sufficient number of large animals (shell length $>12 \mathrm{~mm}$ ) are available for examination. To establish the taxonomic validity of our conclusion, we examined the syntypes of $O$. semistriata in the Natural History Museum in London (catalogue entry: NHMUK 20050254). The seven shells are from 12.6 to 18.2 $\mathrm{mm}$ long, and are in full agreement with our above interpretation. We were unable to locate the type specimen(s) of $O$. columellaris. The oldest publication that we could link to specific specimens was Reeve (1851). The five specimens from the Cuming Collection that served as models for the $O$. columellaris drawing on Table 23 in that monograph are being held in the Natural History Museum London. The four larger shells (14.1 to $14.7 \mathrm{~mm}$ ) show the 'typical' spire callus described above, whereas the fifth measures only $10.6 \mathrm{~mm}$ and lacks the strongly developed callus.

Application of the above identification criteria to published studies leads to surprising results. We are not aware of more than five articles addressing the ecology of Pachyolivae in peer-reviewed journals (Schuster 1952, Schuster-Dieterichs 1956, Seilacher 1959, Vanagt et al. 2008a, 2008b). Ironically, the species seems to have been misidentified in all of them. The older three of these papers (Schuster 1952, Schuster-Dieterichs 1956, Seilacher 1959) reported field work from El Salvador that established basic facts about the behavior, food acquisition, and predator-prey relations of 'O. columellaris'. These publications were cited in more recent review articles (Declerck 1995, Davies \& Hawkins 1998), and Seilacher's (1959 p. 365) beautiful and accurate drawings of a snail deploying its mucus nets were reproduced in several books (Friedrich 1969 p. 270, Hughes 1986 p. 33). However, photographs presented by SchusterDieterichs (1956 p. 19, 21) and Seilacher (1959 p. 359) show mature $O$. semistriata, not $O$. columellaris, and all of the hundreds of shells deposited by Schuster-Dieterichs in the Senckenberg collection that are large enough for identification are $O$. semistriata. Moreover, $O$. semistriata is the only Pachyoliva on the El Salvadorian beaches on which these researchers worked, as we have verified on field trips in 2010. The incorrect identifications may have been due partly to the fact that the characteristic striae on the $O$. semistriata shells had received no mention in Olsson's Olivella monograph (1956), to which Seilacher (1959) refers. More recently, Vanagt et al. (2008a, 2008b) scrutinized the burrowing performance of ' $O$. semistriata' and its circatidal movements on beaches in Ecuador. While these authors do not comment on taxonomy, species identification is discussed in the doctoral dissertation (Vanagt 2007) on which the two papers are based. The photographs given (Vanagt 2007 p. 26 and title page) show typical $O$. columellaris, not $O$. semistriata. While the ecological and physiological conclusions drawn in all of these papers remain largely unaffected by the incorrect species identifications, our taxonomic corrections are essential for an integration of these studies in the wider contexts of biogeography, evolution, and comparative aspects of the species' physiology, ecology, and behavioral biology.

A certain degree of taxonomic confusion regarding Pachyoliva exists in museum collections as well. Twenty-four of the 25 items in the Senckenberg collection that bear $O$. columellaris or $O$. semistriata as species name included mature shells which could be identified unequivocally. Of these items, 11 (46\%) had been misidentified. In contrast, 16 of the 17 identifiable entries in the collection of the Natural History Museum were labelled correctly, which may be due to the fact that the type specimens of $O$. semistriata were available at this institution for comparison. It is worth mentioning that in the Senckenberg collection, all of the five records of supposed $O$. columellaris from Central America in fact are O. semistriata, which reinforces the doubts expressed by Olsson (1956, p. 202) regarding the validity of reports of $O$. columellaris from that region. On the other hand, two of the three records in the Senckenberg collection of supposed $O$. semistriata from Ecuador and Peru in reality are $O$. columellaris. These findings, together with the misidentifications in the published literature discussed above, suggest that reports of $O$. columellaris from Central America and records of O. semistriata from locations south of Colombia tend to be incorrect. Therefore it appears questionable whether the overlap of the distribution ranges of the two species is as broad as suggested by standard identification guides (e.g. Nicaragua to northern Peru, according to Keen 1971 p. 631). It rather appears that $O$. semistriata is the only Pachyoliva north of Colombia whereas $O$. columellaris dominates more or less completely south of that country. This tentative conclusion can be tested in the field using the identification criteria validated in the present study.

\section{Shell Shape and Mode of Development}

Shell geometry may provide essential identification criteria in difficult taxa, such as the Olividae, if strictly quantitative morphometric approaches are followed (Tursch \& German 1985). To see whether identifications of Pachyoliva species based on the shell characters discussed above correlate with shell shape as suggested by current identification guides, we determined simple geometric parameters (Figure 1) in several hundred individuals of each species from our study sites in Costa Rica (O. semistriata) and Peru (O. columellaris), and from the Senckenberg collection. We first plotted shell width versus shell length for the two species to determine whether shells of various populations identified as the same species fell into a common region; in fact, this was the case (Figure 6a, b). An overlay of the two clouds of data-points showed that $O$. columellaris shells actually were 'fatter' than those of $O$. semistriata, but only if they exceeded about $11 \mathrm{~mm}$ length (Figure $6 \mathrm{c}$ ). This fact became even clearer in a plot of aspect ratio (shell length divided by shell width) versus shell length (Figure 6d). A similar result was obtained when we plotted spire height versus spire base width as a measure for the pointedness of the shell. Large, but not small $O$. columellaris had a smaller spire height to spire base width ratio than $O$. semistriata of comparable size (Figure 6e).

Evidently, overall shell shape is a helpful criterion in distinguishing $O$. columellaris and $O$. semistriata, but as in the cases of callus and striae, the criterion is reliable only in individuals above a certain critical size (i.e., about $12 \mathrm{~mm}$ shell length). Most individuals below this size cannot be identified unequivocally. Our data provided further information regarding the developmental mechanisms behind the establishment of the distinct phenotypes in larger individuals. In O. semistriata, simple linear relationships exist between shell length 

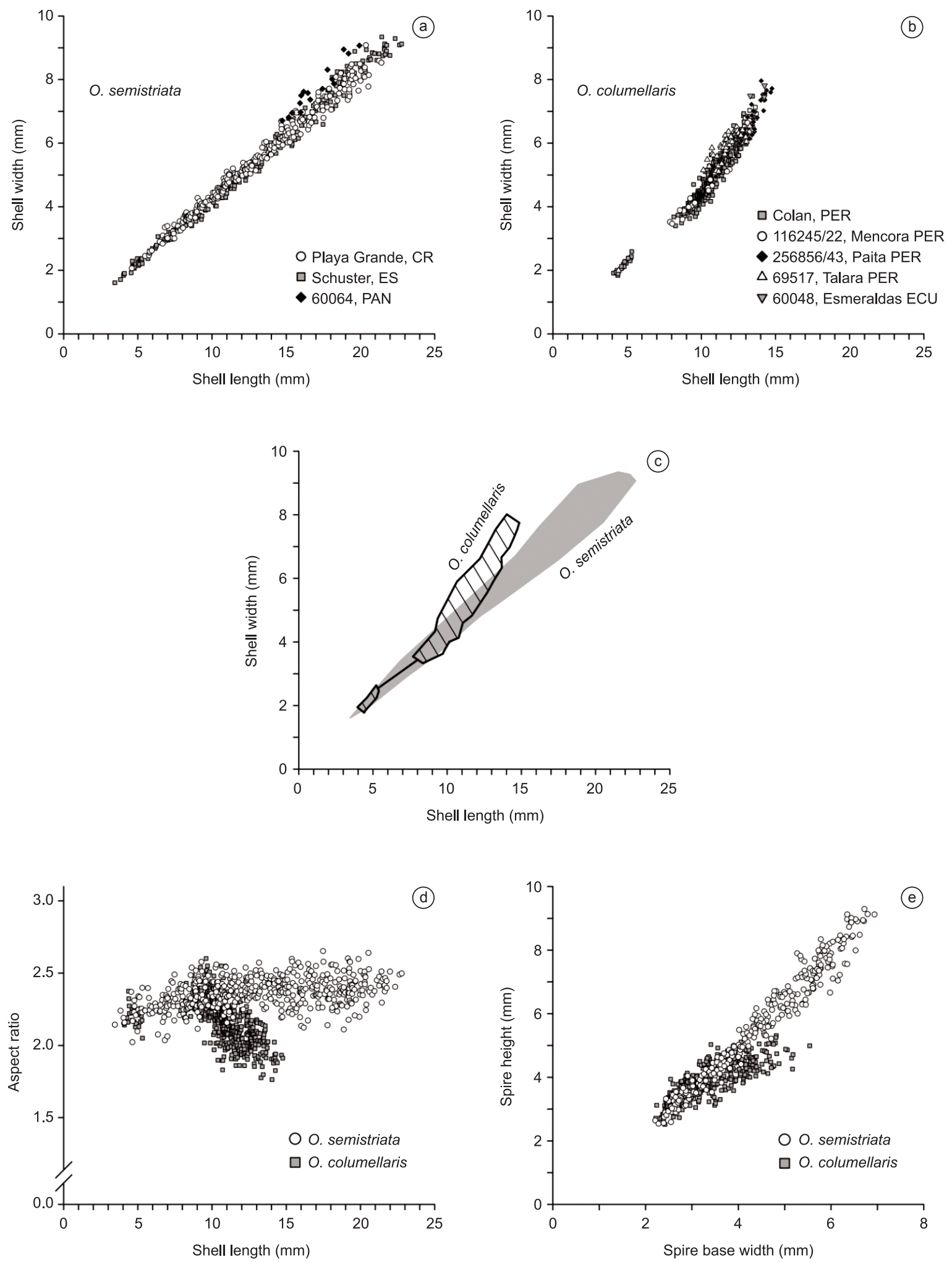

Figure 6. Shell morphometrics of Pachyoliva snails. a) Shell width plotted versus shell length for samples from three $O$. semistriata populations; our study population at Playa Grande, Costa Rica $(n=267)$, the population studied by O. Schuster in El Salvador (shells housed in the Senckenberg collection; $n=201$ ), and a population from Panama (Senckenberg collection, catalogue number 60064; $n=16$ ). b) Analogous data from five populations of $O$. columellaris; our study population at Colan, Peru $(n=413)$, and four populations from Peru and Ecuador (Senckenberg collection, catalogue numbers indicated in the figure; $116245 / 22, n=22 ; 256856 / 43, n=43 ; 69517, n=44 ; 60048, n=3)$. c) Overlay of the data areas in a) and b); only the largest $O$. columellaris shells are wider than $O$. semistriata shells of the same length. d) The plot of shell aspect ratio (shell length divided by width, calculated from data in a) and b)) versus shell length shows that the geometry of shell growth is similar in the two species early in life, but that $O$. columellaris shells tend to become relatively wider when shell length exceeds $10-11 \mathrm{~mm}$. e) Large $O$. columellaris that have spire base widths of $4 \mathrm{~mm}$ or more show lower ratios of spire height to spire base width than $O$. semistriata of comparable size (data from the $O$. semistriata population in Playa Grande, Costa Rica, $n=300$, and the $O$. columellaris population in Colan, Peru, $n=490$ ). 
and width (Figure 6a) as well as between spire base width and spire height (Figure 6e), and the shell aspect ratio was practically constant for all shell sizes (Figure 6d). Thus, O. semistriata does not change its proportions as it grows; growth is isometric, and there is no geometrically defined state of maturity. In contrast, $O$. columellaris changes its mode of shell growth once it reaches $10 \mathrm{~mm}$ shell length; shells grow wider relative to their length (Figure 6b, d) after this stage, and the spire becomes flatter (Figure 6e). This is an allometric growth pattern with geometrically distinguishable immature and mature phases. It should be noted that growth ceases in $O$. columellaris shortly after the switch into the mature growth mode, as we never found shells of more than $15 \mathrm{~mm}$ length (Figure 6b). In contrast, O. semistriata grows isometrically up to $23 \mathrm{~mm}$ (Figure 6a), which significantly exceeds the size given in recent identification keys (15 mm; Burch \& Burch 1963, Keen 1971).

Differences in gastropod shell shape and allometric growth can, in many cases, be explained as a function or even a direct consequence of differences and changes in shell growth rate (Kemp \& Bertness 1984, Urdy et al. 2010a, 2010b). Our analysis of shell morphometrics (Figure 6) allows conclusions regarding geometric aspects of growth, but lack the temporal component required to evaluate growth rates. Growth analyses based on repeated measurements of individual snails over prolonged periods will be required to understand the morphometric relationships quantitatively in terms of temporal processes.

Allometric shell growth in marine gastropods frequently is plastic and responsive to environmental conditions (Kemp \& Bertness 1984, Johnson \& Black 1998, Yeap et al. 2001, Hollander et al. 2006). Purpura columellaris (Thaididae), an inhabitant of hard substrates in the intertidal of the tropical eastern Pacific, shows differences in growth rate leading to shell morphologies so distinct that the faster growing morph had been considered a separate species, $P$. pansa (Wellington \& Kuris 1983). The occurrence of the two morphs correlated with gradients in predation risk (Wellington \& Kuris 1983). Could $O$. columellaris and semistriata be a similar case, and represent two morphs of the same biological species? We think not, because the two taxa do not overlap geographically as broadly as previously assumed (see discussion above), because there are no intermediate adult forms with respect to the decisive trait 'semi-striation', and because the dependency of shell geometry on body size indicates two identifiable clusters of forms rather than a continuum (Figure $6 \mathrm{c}$ ). Moreover, the distribution of the two taxa is not correlated with any obvious environmental factors that could be hypothesized to favor one over the other. Considering all available evidence, it seems more plausible that $O$. columellaris and $O$. semistriata are sister species that have diversified with respect to their genetically fixed developmental programs (isometric versus allometric growth). The occurrence of an allometric shift in shell shape at a defined developmental stage in a member of the Olivellidae is not entirely unexpected; similar cases have been reported from the closely related Olividae (Tursch 1997).

\section{Developmental and ecological plasticity in O. semistriata}

While working at Playa Grande (Costa Rica) where O. semistriata of over $20 \mathrm{~mm}$ shell length occur regularly, we also studied a population at Bahia Junquillal close to the Nicaraguan border (site 8 in Figure 2) which lacks individuals larger than $13 \mathrm{~mm}$ shell length. Since we consistently found this discrepancy at all times of year, it cannot be due to an annual growth cycle or a seasonal developmental pattern in $O$. semistriata. Rather, the species appears to reach different maximum body sizes at different locations. Phenotypic variability in shell size and shape that appears adaptive due to its correlation with biotic or abiotic environmental factors is common in marine gastropods (Wellington \& Kuris 1983, Kemp \& Bertness 1984, Johannesson 1986, Trussell 1996, Yeap et al. 2001, Hollander et al. 2006). Johnson and Black (1998, 2000, 2008) studied phenotypic variability and growth plasticity in the polymorphic Bembicium vittatum (Littorinidae) and reached the conclusion that "[...] the dwarf phenotype is largely a plastic stunting." (Johnson \& Black 1998 p. 95) in response to specific environmental conditions. If the same holds for the 'dwarfish' populations of $O$. semistriata, their occurrence will be correlated with some environmental factor(s).

We tested this hypothesis by comparing maximum body sizes in O. semistriata populations at eight test sites (Figure 2). As a group, the test beaches represented ecological gradients regarding their exposure to wave energy, and with respect to the type and extent of human activities (Table 1). Finally, the test beaches varied significantly with regard to predation pressure on $O$. semistriata, with estimated minimum densities of its main predator Agaronia propatula (López et al. 1988, Rupert \& Peters 2011, Cyrus et al. 2012) between 0 and $>20$ individuals per $100 \mathrm{~m}$ beach length. (Table 1).

Maximum shell length in $O$. semistriata, a parameter that is easily established with minimum disturbance of the animals in their natural environment, differed significantly between the sites (an example is shown in Figure 7a). However, size differences between individuals are most meaningful if expressed in terms of body mass since this reflects the different costs of generating and maintaining a given body size more directly. Therefore we determined the relationship of shell length and live body mass for the $O$. semistriata population at our primary study site, Playa Grande (site 3 in Figure 2 and Table 1). Body mass scaled with shell length to the $2.67^{\text {th }}$ power (Figure $7 \mathrm{~b}$ ), close to the $3^{\text {rd }}$ power that is theoretically expected for the relationship between distance- and volume-dependent parameters in bodies of similar shape.

Since the determination of the largest size class present at a given location rather than the determination of complete size spectra was sufficient to test our hypothesis, we screened each test beach for particularly large specimens following a standardized procedure (see Methods section). We used the size distribution of the largest 25 individuals found at a site as an estimate of the maximum size present at that location. The size spectra of these largest 25 animals found at each site are presented as box-plots in Figure 7c, where they are graphed versus predation pressure as represented by the estimated density of $A$. propatula. It is worth noting that the differences in maximum body size that exist between local populations may be quite substantial (Figure 7c). The estimated maximum body mass in the population with the largest snails (Playa Grande, site 3) was more than four-fold that found in the population with the smallest 'big' snails (Playa Hermosa, site 6).

The maximum size of $O$. semistriata did not correlate with predation pressure (Figure 7c). Neither did the extent of human utilization of the beaches produce any obvious effects: Bahia Junquillal (pristine, remote from settlements, no significant tourist infrastructure; site 8) and Playa Hermosa ('downtown location'; site 6) represented the extreme cases in terms of direct human impact and utilization, but at these two locations the maximum sizes of $O$. semistriata were the lowest observed. However, there was a clear correlation between maximum body size reached at a location and the exposure of that particular beach to wave energy. The three beaches fully exposed to oceanic conditions had the largest $O$. semistriata whereas the three sheltered beaches had the smallest; intermediately exposed beaches had snails of intermediate size (Figure 7c). Evidently, O. semistriata remains small in sheltered coves and grows to large sizes on beaches exposed to the open ocean.

Due to the variability in local maximum size, researchers familiar with specimens from only a few populations might easily 

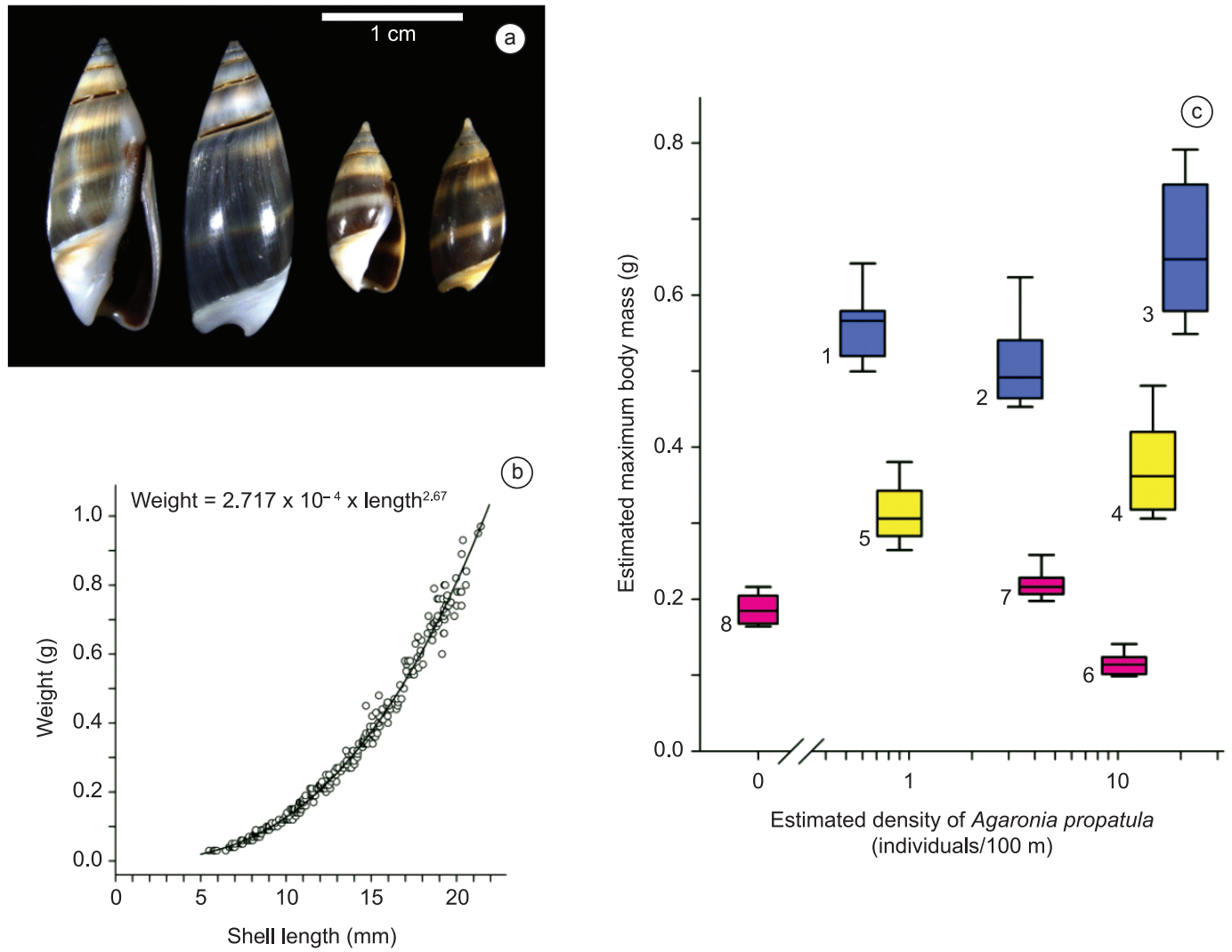

Figure 7. Dependence of maximum body mass reached by $O$. semistriata on local ecological conditions prevailing at selected test beaches (sites 1 to 8 ; see Table 1 and Figure 2 for details). a) Example of size differentiation; representative shells of the largest size classes found at site 2 (Playa Avellana; left) and site 8 (Bahia Junquillal; right). b) Empirical relationship between shell length and body mass established in the population at site 3 (Playa Grande; $n=266$ ). c) Box plots of the body masses of the largest 25 individuals found at each test beach (boxes represent the central quartiles, and whiskers mark the $5^{\text {th }}$ and $95^{\text {th }}$ percentiles of these groups of 25). The abscissa represents the estimated density of the predatory gastropod Agaronia propatula as a measure of the predation pressure $O$. semistriata is exposed to at the test beaches. Box plots are color coded to indicate high (blue), intermediate (yellow), and low (magenta) exposure to wave energy (see Table 1 for further details).

reach invalid conclusions. For example, the maximum shell size in $O$. semistriata is understated by about one third in the current identification literature (Burch \& Burch 1963 p. 5, Keen 1971 p. 632), which suggests that the authors studied specimens exclusively from populations in which only moderate body sizes were reached. In 1851, small $O$. semistriata actually were described as a separate species, 'O. attenuata', by Reeve, an author who obviously was familiar with the typical, large $O$. semistriata. The error was recognized first by Weinkauff in 1878 who, intriguingly, is the only classical author to report similar maximum shell lengths for $O$. semistriata as we do $(22 \mathrm{~mm})$. Weinkauff found that some specimens in batches of collected ' $O$. attenuata' showed the striae typical of $O$. semistriata, and concluded that ' $O$. attenuata' "[...] certainly is nothing but a small variety of $O$. semistriata." (Weinkauff 1878 p. 145; our translation). We infer that the specimens in which Weinkauff saw the typical striation were the very largest ones in those batches, because this is what we found in 'O. attenuata' samples in the collection of the Natural History Museum, London. Snails classified in this collection as 'O. attenuata' usually are below $9 \mathrm{~mm}$ shell length, but the few larger individuals often show faint striae on the posterior body whorl. From these facts it is evident that earlier researchers repeatedly mistook small $O$. semistriata for a different taxon, indicating that they must have encountered populations that lacked larger, semi-striated shells, which would have revealed their true identity. The observed continuation of 'dwarfish' populations over prolonged periods requires at least one of two possible mechanisms. First, the members of the population may acquire reproductive maturity and produce offspring without ever reaching the phenotypic (morphological) maturity observed in other populations. This mechanism would be in line with the open, isometric growth pattern in this species (Figure 6) that may enable the animals to mature physiologically at variable body sizes that are appropriate for different sets of environmental conditions. Alternatively, 'dwarfish' populations may be pseudopopulations, maintained solely through the continuous recruitment of individuals from other areas. Which of the two possibilities is correct in $O$. semistriata cannot be decided on the basis of the information available at this time.

\section{Conclusions}

Considering the ecological significance of Pachyoliva species that is suggested by their large densities, it certainly is desirable to identify them unequivocally in the field in future studies. From our analysis of diagnostic characters, we conclude that the three traits of the shell commonly listed as criteria by which $O$. columellaris and $O$. semistriata can be distinguished - development of parietal and spire callus, presence of striae on the body whorl, and shell shape - work well in large specimens but not in smaller animals which contribute the majority of individuals in all of the populations that we have studied in the field. For the field biologist attempting to establish the identity of a Pachyoliva population, it will be essential to examine the larger individuals of that population. Small animals 
are not identifiable on the basis of shell morphology and will have to be classified through their association with larger, identifiable specimens in the population. Presumably this will be unproblematic in most regions, since no mixed populations of $O$. columellaris and $O$. semistriata have been reported so far. Moreover, the geographic distributions of the two species do not seem to overlap as broadly as has been assumed in the past.

Although our comparative studies on eight test beaches utilized relatively crude measures for the potential impact of human activities and pollution, the beach character in terms of exposure to wave energy, and predation pressure, we obtained support for the idea that $O$. semistriata develops the dwarfish phenotype in response to the physical environment, more specifically low wave exposure. The clear distinction between genetic and environmental control mechanisms of morphological variability has long been considered essential for an understanding of the evolutionary significance of phenotypic variation in gastropods (Johnson \& Black 1998, Trussell \& Etter 2001, Conde-Padin et al. 2009), but whether this distinction is meaningful or even possible also has been doubted (Urdy et al. 2010a). At this time, it remains unclear how much, if any, of the local variability in $O$. semistriata body size is genetically fixed. However, the large differences in body size between populations that can be easily quantified, and the easily accessible, huge numbers of individuals in each local population, make $O$. semistriata a particularly convenient model for the study of the regulation of phenotypic variability. Moreover, the significance of $O$. semistriata's isometric development for this regulation as well as for the evolution of phenotypic plasticity could be addressed through studies including its allometricly growing sister species, $O$. columellaris. With the present paper we have paved the way for such comparative investigations by resolving the taxonomic ambiguities that marred the earlier literature.

\section{Acknowledgements}

Our studies in Costa Rica were supported by an IPFW Undergraduate Summer Research Grant to S.D.R., and by a grant to A.Z.C. from the June Enoch Scholarship Fund through the IPFW Honors Program (thanks to Shree Dhawale for enabling this support). A.I.T. contributed to this project as a volunteer undergraduate research assistant in the labs of W.S.P. and B.F.D. We thank Dawn Stager for assistance with the preparation of shell sections, and Pilar Santidrián Tomillo, the staff at the Goldring Marine Biology Station at Playa Grande, and the Leatherback Trust (www.leatherback.org) for logistic support in Costa Rica, where field work was carried out under the permit number ACT-OR-D-015 to W.S.P. from the Sistema Nacional de Áreas de Conservación, Ministerio del Ambiente y Energia, Costa Rica. W.S.P. studied Olivella biplicata at the Marine Biology Laboratory (University of California, Davis) at Bodega Bay, California, and thanks Jackie Sones and Lisa Valentine for their help. We gratefully acknowledge support at the Senckenberg Museum by Ronald Janssen and at the Natural History Museum London by Kathie Way and Joan Pickering, and thank Klaus-Jürgen Götting, James Haddock, and Thomas Vanagt for helpful discussion. Thanks also to Talia Bugel for the Spanish translation of the abstract.

\section{References}

AERTS, K., VANAGT, T., DEGRAER, S., GUARTATANGA, S., WITTOECK, J., FOCKEDEY, N., CORNEJO-RODRIGUEZ, M.P., CALDERÓN J. \& VINCX, M. 2004. Macrofaunal community structure and zonation of an Ecuadorian sandy beach. Belg. J. Zool. 134:17-24.

BOUCHET, P. \& ROCROI, J.-P. 2005. Classification and nomenclator of gastropod families. Malacologia 47:1-397.
BURCH, J.Q. \& BURCH, R.L. 1963. Genus Olivella in eastern Pacific. Nautilus 77:1-8. Plus 3 plates.

CONDE-PADIN, P., CABALLERO, A. \& ROLÁN-ALVAREZ, E. 2009. Relative role of genetic determination and plastic response during ontogeny for shell-shape traits subjected to diversifying selection. Evolution 63:1356-1363.

CONRAD, T.A. 1849. The following new and interesting shells are from the coasts of lower California and Peru, and were presented to the academy by Dr. Thomas B. Wilson. Proc. Acad. Nat. Sci. Philadelphia 4:155-156.

CYRUS, A.Z., RUPERT, S.D., SILVA, A.S., GRAF, M., RAPPAPORT, J.C., PALADINO, F.V. \& PETERS, W.S. 2012. The behavioral and sensory ecology of Agaronia propatula (Olividae, Caenogastropoda), a swashsurfing predator on sandy beaches of the panamic faunal province. J. Mollus. Stud. 78:235-245. http://dx.doi.org/10.1093/mollus/eys006

DAVIES, M.S. \& HAWKINS, S.J. 1998. Mucus from marine molluscs. Adv. Mar. Biol. 34:1-71.

DECLERCK, C.H. 1995. The evolution of suspension feeding in gastropods. Biol. Rev. 70:549-569.

FRIEDRICH, H. 1969. Marine biology. University of Washington Press, Seattle.

GRAY, J.E. 1839. Molluscous animals, and their shells. In The Zoology of Captain Beechey's Voyage (J. Richardson, N.A. Vigors, G.T. Lay, E.T. Bennett, R. Owen, J.E. Gray, W. Buckland \& G.B. Sowerby, eds.). Henry G. Bohn, London, p.101-155.

HOLLANDER, J., ADAMS, D.C. \& JOHANNESSON, K. 2006. Evolution of adaptations through allometric shifts in a marine snail. Evolution 60:2490-2497.

HUGHES, R.N. 1986. A functional biology of marine gastropods. Johns Hopkins University Press, Baltimore.

JOHANNESSON, B. 1986. Shell morphology of Littorina saxatilis Olivi: the relative importance of physical factors and predation. J. Exp. Mar. Biol. Ecol. 102:183-195.

JOHNSON, M.S. \& BLACK, R. 1998. Effects of habitats on growth and shape of contrasting phenotypes of Bembicium vittatum Philippi in the Houtman Abrolhos Islands, Western Australia. Hydrobiologia 378:95-103.

JOHNSON, M.S. \& BLACK, R. 2000. Associations with habitat versus geographic cohesiveness: size and shape of Bembicium vittatum (Gastropoda: Littorinidae) in the Houtman Abrolhos Islands. Biol. J. Linnean Soc. 71:563-580.

JOHNSON, M.S. \& BLACK, R. 2008. Adaptive responses of independent traits to the same environmental gradient in the intertidal snail Bembicium vittatum. Heredity 101:83-91.

KEEN, A.M. 1971. Sea shells of tropical west America. Stanford University Press, Stanford.

KEMP, P. \& BERTNESS, M.D. 1984. Snail shape and growth rates: evidence for plastic shell allometry in Littorina littorea. Proc. Nat. Acad. Sci. USA 81:811-813.

LAWS, E.A. \& ARCHIE, J.W. 1981. Appropriate use of regression analysis in marine biology. Mar. Biol. 65:13-16.

LÓPEZ, A., MONTOYA, M. \& LÓPEZ, J. 1988. A review of the genus Agaronia (Olividae) in the panamic province and the description of two new species from Nicaragua. Veliger 30:295-304.

OLSSON, A.A. 1923-1924. Notes on marine molluscs from Peru and Ecuador. Nautilus 37:120-130.

OLSSON, A.A. 1956. Studies on the genus Olivella. Proc. Acad. Nat. Sci. Philadelphia 108:155-225.

REEVE, L.A. 1851. Monograph of the genus Oliva (Conchologia Iconica 6). L. Reeve \& Co., London.

RUPERT, S.D. \& PETERS, W.S. 2011. Autotomy of the posterior foot in Agaronia (Olividae, Caenogastropoda) occurs in animals that are fully withdrawn into their shells. J. Mollus. Stud. 77:437-440.

SCHUSTER, O. 1952. Olivella columellaris un caracol de la playa de Los Blancos. Comm. Inst. Tropical Invest. Cientif., Univers. El Salvador 4:10-13. 
SCHUSTER-DIETERICHS, O. 1956. Die Makrofauna am sandigen Brandungsstrand von El Salvador (mittelamerikanische Pazifikküste). Senckenberg. Biol. 37:1-56.

SEILACHER, A. 1959. Schnecken im Brandungssand. Natur u. Volk 89:359-366.

SOWERBY, G.B. 1825. A catalogue of the shells contained in the collection of the late Earl of Tankerville, arranged according to the Lamarckian conchological system; together with an appendix, containing descriptions of many new species. E.J. Sterling, London.

TRUSSELL, G.C. 1996. Phenotypic plasticity in an intertidal snail: the role of a common crab predator. Evolution 50:448-454.

TRUSSELL, G.C. \& ETTER, R.J. 2001. Integrating genetic and environmental forces that shape the evolution of geographic variation in a marine snail. Genetica 112-113:321-337.

TURSCH, B. 1997. Non-isometric growth and problems of species delimitation in the genus Oliva. Apex 12:93-100.

TURSCH, B. \& GERMAIN, L. 1985. Studies on the Olividae. I. A morphometric approach to the Oliva problem. Indo-Malay. Zool. 2:331-352.

URDY, S., GOUDEMAND, N., BUCHER, H. \& CHIRAT, R. 2010a. Growth-dependent phenotypic variation of molluscan shells: implications for allometric data interpretation. J. Exp. Zool. (Mol. Develop. Evol.) 314B:280-302. PMid:20084667. http://dx.doi.org/10.1002/ jez.b.21338
URDY, S., GOUDEMAND, N., BUCHER, H. \& CHIRAT, R. $2010 \mathrm{~b}$. Allometries and the morphogenesis of the molluscan shell: a quantitative and theoretical model. J. Exp. Zool. (Mol. Develop. Evol.) 314B:303-326. PMid:20084667. http://dx.doi.org/10.1002/jez.b.21337

VANAGT, T. 2007. The role of swash in the ecology of Ecuadorian sandy beach macrofauna, with special reference to the surfing gastropod Olivella semistriata. $\mathrm{PhD}$ thesis, Ghent University, Belgium. http://www.vliz.be/ imisdocs/publications/125753.pdf (last accessed 05/11/2011).

VANAGT, T., VINCX, M. \& DEGRAER, S. 2008a. Can sandy beach molluscs show an endogenously controlled circatidal migrating behaviour? Hints from a swash rig experiment. Mar. Ecol. 29 (Suppl. 1):118-125.

VANAGT, T., VINCX, M. \& DEGRAER, S. 2008b. Is the burrowing performance of a sandy beach surfing gastropod limiting for its macroscale distribution? Mar. Biol. 155:387-397.

WEINKAUFF, H.C. 1878. Die Gattung Oliva (Systematisches ConchylienCabinet von Martini und Chemnitz, Vol. 5 Abt. 1). Bauer \& Raspe, Nürnberg.

WELLINGTON, G.M. \& KURIS, A.M. 1983. Growth and shell variation in the tropical eastern Pacific intertidal gastropod genus Purpura: ecological and evolutionary implications. Biol. Bull. 164:518-535.

YEAP, K.L., BLACK, R. \& JOHNSON, M.S. 2001. The complexity of phenotypic plasticity in the intertidal snail Nodilittorina australis. Biol. J. Linnean Soc. 72:63-76. 


\section{Errata}

TROOST, A.I., RUPERT, S.D., CYRUS, A.Z., PALADINO, F.V., DATTILO, B.F. \& PETERS, W.S. What can we learn from confusing Olivella columellaris and $O$. semistriata (Olivellidae, Gastropoda), two key species in panamic sandy beach ecosystems? Biota Neotrop. 12(2): http://www.biotaneotropica.org.br/v12n2/en/abstract?article+bn02112022012

Página 101

Onde se lê:

of dwarfish O. semistriat, which

Leia-se:

of dwarfish O. semistriata, which

Página 101

Onde se lê:

O. semistriata; O. columellaris; O. columellaris; Olivella columellaris

Leia-se:

O. semistriata; O. columellaris; O. columellaris Olivella columellaris

\section{Página 104}

Onde se lê:

City beach of Puntarenas (W)

Leia-se:

City beach of Puntarenas

\section{Página 105}

Onde se lê:

and the most anterior portion of the foot (prododium) is

\section{Leia-se:}

and the most anterior portion of the foot (propodium) is

\section{Página 110}

Onde se lê:

population at Bahia Junquillal close to the Nicaraguan border (site 2

\section{Leia-se:}

population at Bahia Junquillal close to the Nicaraguan border (site 8

\section{Página 110}

\section{Onde se lê:}

0 and $>20$ per $100 \mathrm{~m}$ beach length

\section{Leia-se:}

0 and $>20$ individuals per $100 \mathrm{~m}$ beach length

\section{Página 112}

Onde se lê:

J. Mollus. Stud. 1-11

Leia-se:

J. Mollus. Stud. 78:235-245

Página 113

Onde se lê:

SCHUSTERDIETERICHS

Leia-se:

SCHUSTER-DIETERICHS

\section{Página 110}

\section{Onde se lê:}

becomes flatter (Figure 6f). This is an allometric growth

Leia-se:

becomes flatter (Figure 6e). This is an allometric growth 


\section{Errata}

TROOST, A.I., RUPERT, S.D., CYRUS, A.Z., PALADINO, F.V., DATTILO, B.F. \& PETERS, W.S. What can we learn from confusing Olivella columellaris and O. semistriata (Olivellidae, Gastropoda), two key species in panamic sandy beach ecosystems? Biota Neotrop. 12(2): http://www.biotaneotropica.org.br/v12n2/en/abstract?article+bn02112022012

\section{Página 103}

Onde se lê:

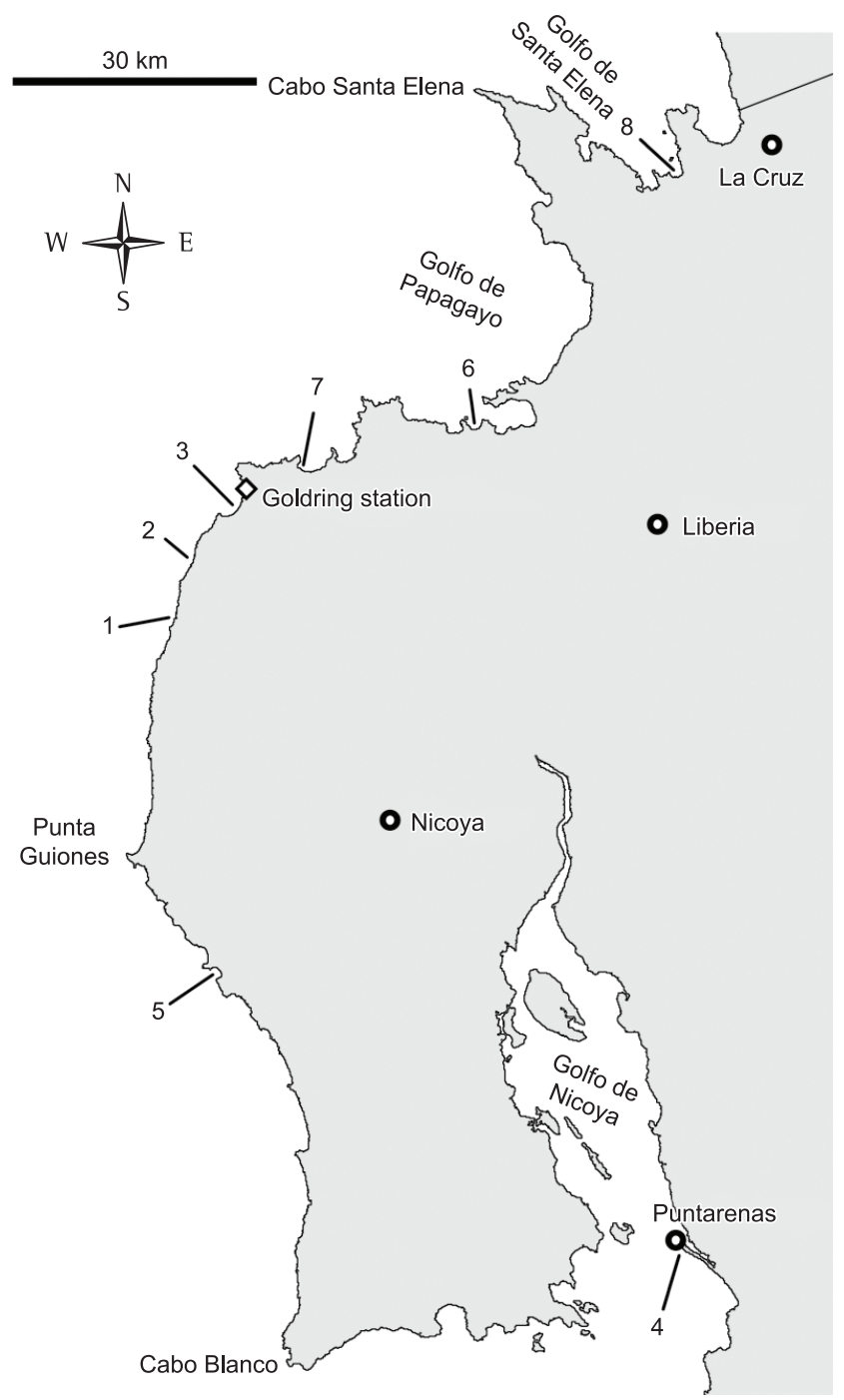

\section{Leia-se:}

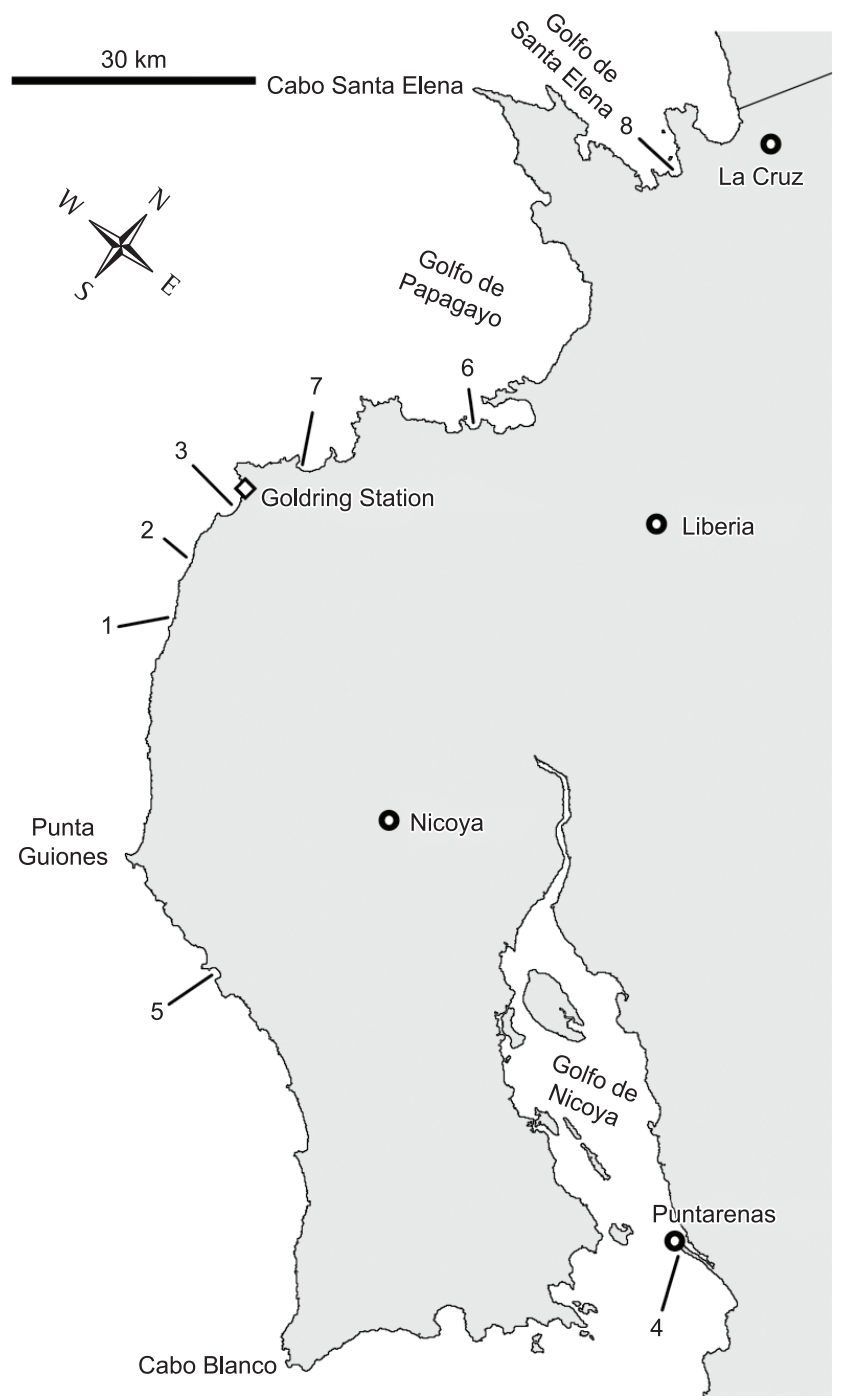




\section{Errata}

TROOST, A.I., RUPERT, S.D., CYRUS, A.Z., PALADINO, F.V., DATTILO, B.F. \& PETERS, W.S. What can we learn from confusing Olivella columellaris and O. semistriata (Olivellidae, Gastropoda), two key species in panamic sandy beach ecosystems? Biota Neotrop. 12(2): http://www.biotaneotropica.org.br/v12n2/en/abstract?article+bn02112022012

\section{Página 111}

Onde se lê:

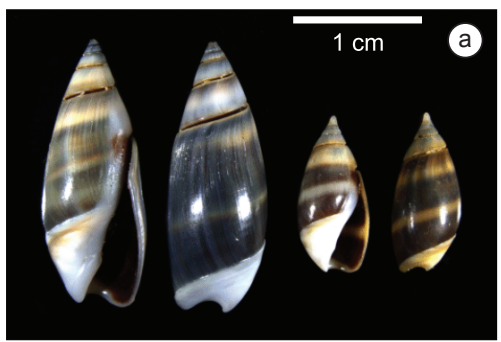

(b)

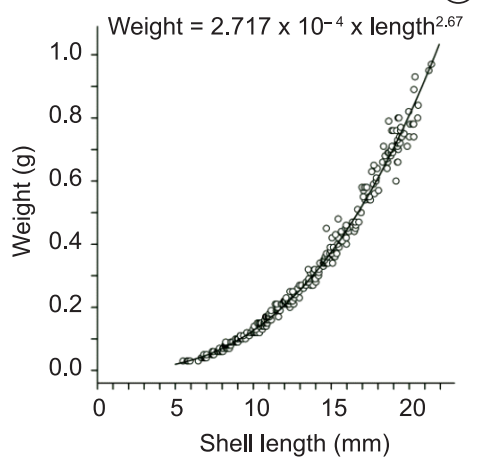

Leia-se:

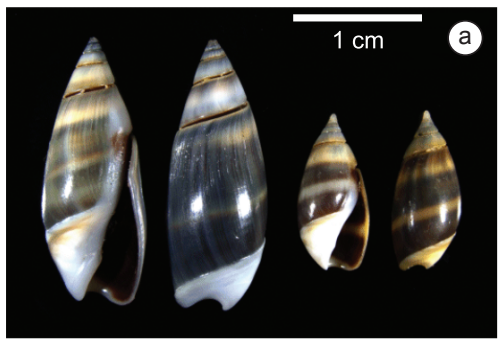

(b)

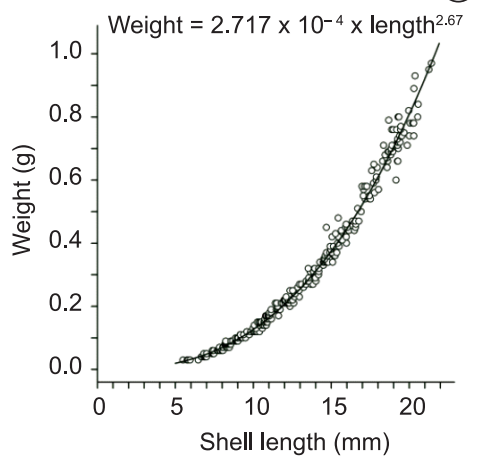

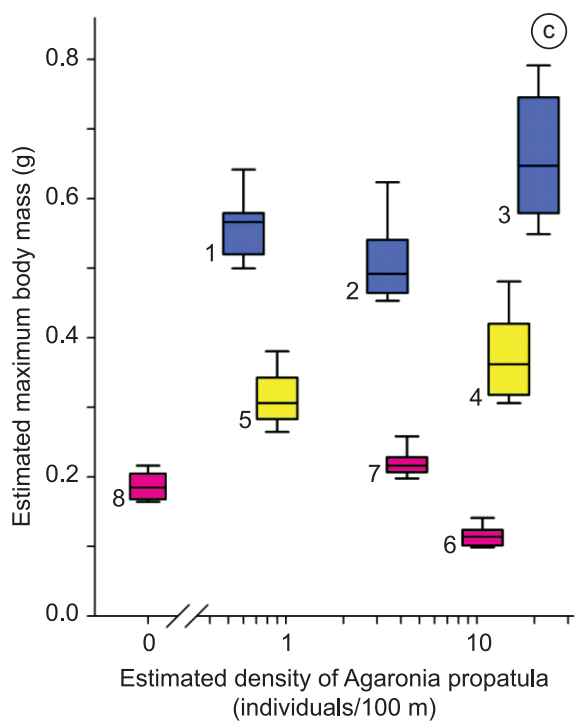

(C) 